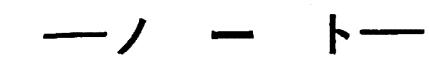

\title{
アニリンの存在におけるジフェニルジクロルシランの加水分解
}

(昭和 33 年 9 月 25 日受理)

滝口利夫*

\section{1. 楮贯}

ジフェニルシランジオール（以下ジオールと略す）の生成につ いては従来いくつかの報告1)があるが，その多くはジフェニルジ クロルシラン (DPDS) の加水分解ならびにその後の単離, 精製等 の操作を出来5るかぎり均一，かつ中性に近い状態で行い，ポリ 縮合によるジオールの収率低下を防ぐことに重点をおいている。

著者は既報 ${ }^{2)}$ に拉いて二，三のオルガノクロルシランがエーテ ル中に拈いてアニリンと反応，定量的に塩酸アニリンを沈殿する ことをみとめ, この現象を試薬中の微量水分に基因するものと推 定したが Si を含む生成物を同定し得なかったため確証を得るに 至らなかった。著者はその後の実験に扣いて塩酸アニリンを除い た液相部分から対応するシラノールの二,三を単離, 確認し，特に DPDS の場合には両者を適当な条件のもとにェーテル中で反応,

適当な方法で夜相部を処理することによりほぼ定量的にジオール を得ることを見出し，この方法をジオールの一合成法として推奖 しうることを認めるとともに，その諸性質について二，三の知見 を得たので報告する。

\section{2. 実験および考察}

2.1 試薬 DPDS は信越化学工業株式会社製のものを蒸留精 製して用いた。アニリンは市販 1 䄲品を $\mathrm{KOH}$ で乾燥した後 10 $\mathrm{mmHg}$ で蒸留 $69 \sim 70^{\circ} \mathrm{C}$ の留分をとり，これに $1 / 5$ (重量) 前後 の蒸留水を加え，更に精製アセトンを少量ずつ加え透明な溶液と して用いた。エーテルは Naで十分乾燥した後蒸留したものを用 いた。

2.2 ジオールの生成 $1 l$ フラスコにエーテル $200 \mathrm{cc}$ 前後を とり，これに DPDS 5〜25 g を加え，更にクリスタルハイオレ ットの $0.5 \%$ アトン溶液数滴を加える。はげしくかきまぜなが らさきのアニリン溶液を滴下すると直ちに白色クリーム状沈殿が 出来る。アニリンの滴下とともにフラスコ内容物は白緑色より白 青色をへて白紫色に急変する。劝殿が凝集しかきまぜによって消 失しない明瞭な白紫色を認めるに至ってアニリンの添加をやめ, フラスコ全内容物を吸引口過する。沈殿（塩酸アニリン）は十分 乾燥エーテルで洗浄, 洗液は口夜に合する。口液は大部分のエー テルを留去したのち真空中で乾燥する。析出した粗結晶塊は少量

†本報告を「オルガノクロルシランに関する研究（第 7 報）」 とする．第 6 報, 工化 62,148 (1959).

* 群馬大学工学部応用化学科 : 桐生市天神町.

1) W. Dilthey, F. Eduardoff, Ber. 37, 1139 (1904); G. Martin, ibid. 45, 403 (1912); F. S.Kipping, J.Chem. Soc. 101, 2108 (1912); F. S. Kipping, R. Robinson, ibid. 105, 487 (1914); C. A. Burkhard, J. Am. Chem. Soc. 67, 2173 (1945); J. F. Hyde, R. C. DeLong, ibid. 63, 1194 (1941); 福川, 科学々工業 30, 71 (1956).

2) 滝口, 工化 61, 1236 (1958).
の脱水ヘンンゼンで洗浄して未反応成分を除いた後十分水洗して塩 酸アニリンのこん跡を除き, 風乾後醀酸メチルより再結晶すると 美麗な白色針状結晶を得る。

2.3 ジオールの性状および諸定数 得られた結晶はエタノー ル,メタノール，アセトンに易溶，低級酿酸エステル，クロロホ ルムに可溶, ベンゼン, トルエンに冷時難溶, 水には不溶であっ た。溶液の酸、アルカリに対する举動は従来の報告1)と一致する。 氷酢酸中の分子量は 197〜208 を与える（計算值 216）。Gilman 反応 ${ }^{9}$ は陽性を示し Zerewitinoff 法4)による - OH (mol) は平均 1.96 を示す。湿式酸化法による Si\% 12.80 である（計算值 $12.97 \%)$ 。粉末の融点は従来の文献)同様一定せず，また測定時 の㫒温速度によっても異なり $1^{\circ} \mathrm{C} / \mathrm{min}$ に执いて $110^{\circ} \mathrm{C}$ 付近より 軟化し， $115 \sim 127^{\circ} \mathrm{C}$ の間に氺いて溶融する。過量の良溶剂から 徐々に成長した単結晶についても融点は一様でなく，134 ${ }^{\circ} \mathrm{C}, 148$ ${ }^{\circ} \mathrm{C}, 155^{\circ} \mathrm{C}$ の 3 種類が存在し，いずれる融点に执いて分解の徵候 を示し，いったん融解した後固化したものの融点は著しく低下す る※1。融点の測定は十分酸に浸漬した後水洗した硬質ガラス毛細 管の使用を必要とし，未処理の軟質ガラスを用いるときは融点は かなり不明確となり，かつ低下する。単結晶を十分粉碎した試料 のX線回折図は $12.8 \AA, 11.8 \AA, 4.87 \AA, 4.76 \AA, 4.44 \AA$, 3.87 A， $3.47 \AA ， 2.99 \AA$ に顕著な回折環を有し，また錠剤法による 赤外線吸収スペクトルは Tatlock ら5゙をって与えられたるのと 完全な一致を示し $\left(\mathrm{C}_{6} \mathrm{H}_{5}\right)_{2} \mathrm{Si}(\mathrm{OH})_{2}$ と同定された。

2.4. 実験結果および考察 結果は表 1 に示した。表中使用ア ニリン量は上記アニリン溶液の濃度を既報2)の方法で決定, 使用 cc 数から算出した。

表 1 ジオール，塩酸アニリンの収量

\begin{tabular}{|c|c|c|c|c|c|c|c|c|}
\hline \multirow[b]{2}{*}{ No. } & \multirow[b]{2}{*}{$\begin{array}{l}\text { DPDS } \\
(\mathbf{g})\end{array}$} & \multirow{2}{*}{$\begin{array}{l}P=y= \\
\text { 使角量 } \\
(\mathrm{g})\end{array}$} & \multirow{2}{*}{$\begin{array}{c}\text { アニリン } \\
\text { DPDS } \\
(\text { (モル比) }\end{array}$} & \multirow{2}{*}{ 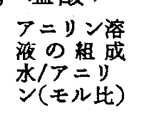 } & \multicolumn{2}{|c|}{ 塩酸アニシン } & \multicolumn{2}{|c|}{ シシオール } \\
\hline & & & & & 收 & 收 事) & 收 & $\begin{array}{l}\text { 收 (\%) } \\
\text { (\%) }\end{array}$ \\
\hline 1 & 7.9 & 6.1 & 2.1 & 1.02 & 8.3 & 98 & 6.1 & 90 \\
\hline 2 & 10.0 & 7.4 & 2.0 & 1.02 & 10.2 & 99 & 7.8 & 91 \\
\hline 3 & 17.4 & 12.9 & 2.0 & 0.90 & 17.8 & 99 & 13.7 & 92 \\
\hline 4 & 24.6 & 19.1 & 2.1 & 0.90 & 26.3 & 99 & 19.4 & 92 . \\
\hline 5 & 9.0 & 6.3 & 1.9 & 2.03 & 6.8 & 78 & 5.9 & 77 \\
\hline 6 & 8.6 & 6.0 & 1.9 & 1.60 & 6.8 & 81 & 5.8 & 79 \\
\hline 7 & 14.3 & 8.5 & 1.6 & 1.60 & 9.9 & 84 & 9.1 & 74 \\
\hline 8 & 7.5 & 2.0 & 0.7 & アニリンのみ & 2.2 & 80 & 2.0 & 31 \\
\hline 9 & 4.9 & 1.6 & 0.9 & アニリンのみ & 1.8 & 81 & 1.5 & 36 \\
\hline
\end{tabular}

表 1 中́の No. 1 4 4なわち当モルのアニリンおよび水を含む 溶液との反応において両生成物がほぼ定量的に生成する事実は本 実験の反応機構が次式により端的に表わされることを明暸に示す。 $\left(\mathrm{C}_{6} \mathrm{H}_{5}\right)_{2} \mathrm{SiCl}_{2}+2 \mathrm{H}_{2} \mathrm{O}+2 \mathrm{C}_{6} \mathrm{H}_{5} \mathrm{NH}_{2} \longrightarrow$

$$
\left(\mathrm{C}_{6} \mathrm{H}_{5}\right)_{2} \mathrm{Si}(\mathrm{OH})_{2}+2 \mathrm{C}_{6} \mathrm{H}_{5} \mathrm{NH}_{3} \mathrm{Cl}
$$

3) H. Gilman, et al, J.Am. Chem. Soc. 76, 918 (1954).

4) 日化編，化学便覧 p. 1332 (昭和 33 年版).

※1 融解時の変化および生成物については後報において検討の 予定.

5) W.S. Tatlock, E. G. Rochow, J. Org. Chem. 17, 1555 (1952). 
No. 5〜7 における両生成物の収率の低下は次のよ5に考えられ る。すなわらこの実験においては $\mathrm{HCl}$ の受容剤であるアニリン が不足のため $\mathrm{HCl}$ は一部遊離の状態で夜相部に残存し, ジオー ルの樎合を促進して高重合物の生成を許容し, ジオールの収率を 低下する。No. 8，9 においては口夜は相当量の遊離 DPDS を含 み，その後の操作中に再結晶し難いポリマーおよび少量の環状 3 量体を生じ, ジオールの収率は著しく低下する。

また本実験を通じてみとめた興味ある事実は反応系中の水分は
完全に消費される結果口夜を蒸留して得るエーテルは完全無水に 近い状態であり，純ナトリウムの新たな切断面に対し全く不活性 である。他のクロルシランとの反応に扣ける生成物については現 在実施中である。

X線資料の作製を担当していたたいた日本化学工業株式会社柏 瀬弘之, 田部井清吉の両氏ならびに赤外線凟料の作製に御尽力を 戴いた本学大谷杉郎氏, 東北大非水溶液化学研究所池上雄作氏に 深甚の感謝の意を表する。

\title{
一研 究 速 報一
}

\section{イオン交換樹脂法によるホウ素の同位体濃縮}

（昭和 34 年 1 月 12 日受理)

\author{
米田幸夫*.内島俊雄** 牧島象二*
}

$0.03 \mathrm{M}-\mathrm{H}_{3} \mathrm{BO}_{3}$ 水溶液 (I) および $0.1 \mathrm{M}-\mathrm{H}_{3} \mathrm{BO}_{3}$-水一グ リセリン (8wt \%) 泥合溶液 (II) を R-OH 形樹脂柱に 流下させ，これから分離係数を求めた。

カラムは 2 本で, 前処理をした $\mathrm{R}-\mathrm{OH}$ 形 Amberlite CG-400-I (IRA-400 相当, クロマト用, 100 200 メッシ ュ）の高さ約 $120 \mathrm{~cm}$ の樹脂層で, 交換容量は約 650 㧊よ び $900 \mathrm{meq}\left(\mathrm{H}_{2} \mathrm{BO}_{3}{ }^{-}\right)$である。I または II を $0.5 \sim 0.7$ $\mathrm{cc} / \mathrm{min}$ の流速で流下させた。交換定数が大きいため, 前端 はかなり明瞭である。 $\mathrm{OH}^{-}$がすべて $\mathrm{H}_{2} \mathrm{BO}_{3}-$ (吸着イオン の形態が不明のため, ホウ酸の弱酸性を考虑して $\mathrm{H}_{2} \mathrm{BO}_{3}{ }^{-}$ と仮定, この仮定は分離係数に影響しない。)で置換された あとの流出液のホウ酸濃度, 同位体比を測定した結果, ${ }^{10} \mathrm{~B}$ が樹脂相に濃樎された(図 1 )。横軸は流出液中の $\mathrm{H}_{2} \mathrm{BO}_{3}-$ のミリ当量の積算値をカラムの容量の分数で表わしたもの である。ホウ酸からの $\mathrm{B}_{2} \mathrm{O}_{3}$ を $\mathrm{CoF}_{3}$ でフッ素化して得た $\mathrm{BF}_{3}{ }^{1)}$ を質量分析計にかけて, 同位体比を求めた。原料ホ ウ酸中の ${ }^{10} \mathrm{~B}$ の原子分率 $N_{0}$ は $19.70 \%$ であった $* 1$ 。

一方, 畭燥口紙でロ過脱水した $\mathrm{R}-\mathrm{OH}$ 形脂樹と数種の 濃度の溶液との間で交換容量をバッチ法で测定し, 内挿に より I (4.36 meq $\mathrm{H}_{2} \mathrm{BO}_{3}^{-} / \mathrm{g}$ 樹脂(風乾)) をたは II ( $4.65 \mathrm{meq} /$ g) との交換容量を求めた。な拈, $\mathrm{OH}^{-}$交換容量は $2.65 \mathrm{meq} / \mathrm{g}$ であった。

図 1 で $N$ が $N_{0}$ に等しくなる点まで外挿すれば, Spedding ら $の$ の法で $\mathrm{R}-\mathrm{H}_{2}{ }^{11} \mathrm{BO}_{3}+\mathrm{H}_{3}{ }^{10} \mathrm{BO}_{3} \longrightarrow \mathrm{R}-\mathrm{H}_{2}{ }^{10} \mathrm{BO}_{3}+\mathrm{H}_{3}{ }^{1{ }^{1} \mathrm{BO}_{3}}$ なる交 換反応の 分離係数 $\alpha \equiv\left({ }^{10} \mathrm{~B} /{ }^{11} \mathrm{~B}\right)_{\mathrm{R}} /\left({ }^{10} \mathrm{~B} /{ }^{11} \mathrm{~B}\right) \mathrm{s}$ ( $\mathrm{R}$ : 樹脂相, $\mathrm{S}$ : 溶 夜相) が求められる。 $\alpha(\mathrm{I})=1.010_{0}, \alpha(\mathrm{II})=1.016_{6}$ で大量分離 にも不適当ではない。

予備実験によればホウ酸の濃度が大であれば $\alpha$ は小さくなる のでI と II との差はグリセリン添加の効果で, 周知の酸性增加 と関連すると思われる。目下, 濃度, 添加物, イオン種, 溶媒の 効果および，ホウ酸錯イオンの挙動を研究中である。

* 東京大学工学部応用化学科：東京都文京区.

** 現勤務先：日本原子力研究所東海研究所: 茨城県東海村.

1) I. Kirschenbaum, U.S. P. 2,622, 014, Dec. 16 (1952).

※1 ホウ素の天然存在比は試料によってかなり異なっている.

2) F.H.Spedding, J.E. Powell, H. J.Svec, J. Am. Chem. Soc. 77,6125 (1955).

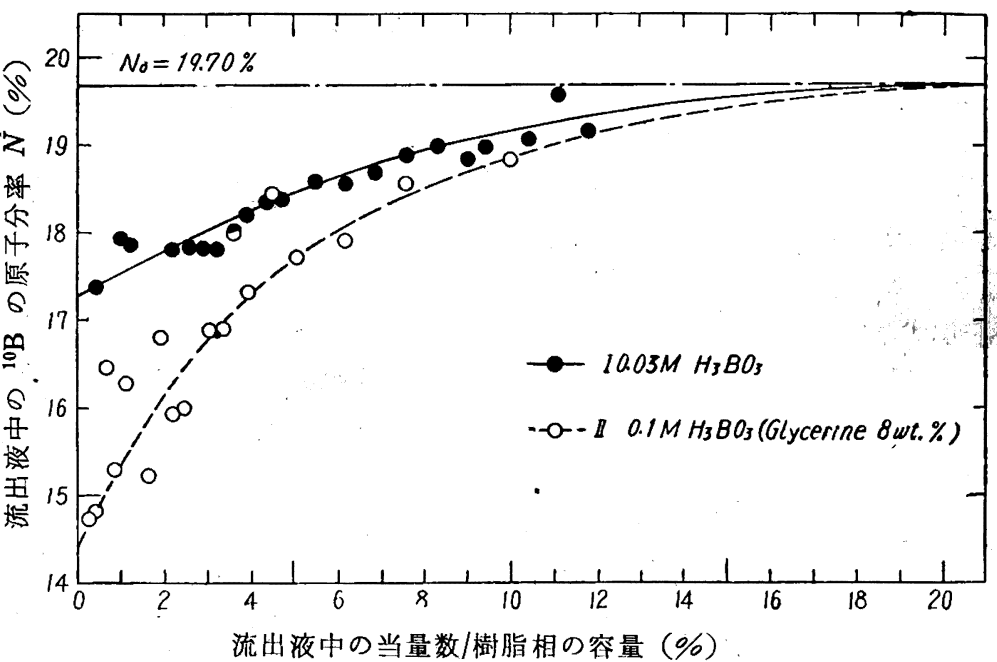

図 1

（昭和 33 年 4 月，日化第 11 年会にて講演発表）

本研究の経費は昭和 32 年度文部省機関研究費で支弁した。ま た荒木 峻助教授には質量分析計について御教示を得, 望月不 二雄助手の協力を得た。交換樹脂は日本オルガノ商会から， CoFs は大阪金属工業（株）より供与された。あわせて感謝する。

明和 34 年 4 月 2 日 印刷明和 34 年 4 月 5 日 発行 [定伍 200 円（送料 $15 \mathrm{~m}$ 円)]

発行获

印刷人

印刷 所 東京都于代田区神田雅河台 1 の 5

東京都新宿区市ヶ谷本村町 27 東京都新宿区市ヶ谷本村町 27

岩城広吉 平尾秀吉 新日本印刷栐式会社

発行所東京都千代田区（神田局区内）神田雅河台 1 の 5

社団法人日本化学会

振替拧金口座東京第 6058 番

電話東京二九 (29) $0637 \sim 0639$ 